\title{
Deskripsi Representasi Grafik Fungsi Trigonometri Mahasiswa Berbantuan Media Geogebra
}

\author{
Mohammad Archi Maulyda ${ }^{1}$, Erry Hidayanto ${ }^{2}$, Swasono Rahardjo $^{2}$ \\ ${ }^{1}$ Universitas Mataram \\ ${ }^{2}$ Pendidikan Matematika-Universitas Negeri Malang
}

\begin{tabular}{l}
\hline \hline INFO ARTIKEL \\
\hline Riwayat Artikel: \\
Diterima: 19-03-2019 \\
Disetujui: 17-09-2019 \\
\hline
\end{tabular}

\section{Kata kunci:}

geogebra;

trigonometry;

representation;

geogebra;

trigonometri;

representasi

\author{
Alamat Korespondensi: \\ Mohammad Archi Maulyda \\ Universitas Mataram \\ Jl. Majapahit, No. 62, Gomong, Mataram, Nusa Tenggara Barat \\ E-mail: archimaulyda@unram.ac.id
}

\begin{abstract}
Abstrak: Tujuan penelitian kualitatif deskriptif adalah untuk mendeskripsikan bentuk representasi matematis yang muncul ketika mahasiswa memahami hubungan antara perubahan koefisien fungsi trigonometri dengan grafik fugsinya lewat media GeoGebra. Mahasiswa dalam satu kelas yang berjumlah 30 mahasiswa dipilih sebagai subjek penelitian dan diberikan Lembar Kerja Mahasiswa. Dari hasil pekerjaan mahasiswa tersebut, terlihat ada tiga tipe kecenderungan bentuk representasi yang digunakan mahasiswa untuk menyelesaikan Lembar Kerja. Dari tiga tipe kecenderungan tersebut masing-masing diambil satu mahasiswa yang akan dibahas lebih lanjut hasil pekerjaanya secara random karena dinilai dapat mewakili hasil pekerjaan mahasiswa yang lain. Hasil penelitian menunjukan bahwa mahasiswa merepresentasikan tampilan Geogebra dalam tiga bentuk, yakni representasi verbal, representasi ekpresi matematis, dan representasi visual.
\end{abstract}

Salah satu kemampuan dasar yang harus dimiliki anak dalam mempelajari matematika adalah kemampuan representasi matematis. The National Council of Teachers of Mathematics (2000) telah menjelaskan bahwa setiap siswa wajib memiliki setidaknya lima kemampuan dasar dalam belajar matematika, meliputi (1) Problem Solving, (2) Reasoning and Prove, (3) Communication, (4) Connection, (5) Representation. Bukan hanya untuk anak yang berada pada jenjang sekolah dasar, menengah hingga atas (siswa) namun juga untuk anak yang berada pada jenjang perguruan tinggi. Proses perkuliahan dan matakuliah di perguruan tinggi yang lebih kompleks, menuntut mahasiswa memiliki lima kemampuan dasar yang telah dirumuskan NCTM. Menurut Rusmini \& Surya (2017), dalam mempelajari matematika mahasiswa dituntut memiliki kemampuan bernalar dan representasi yang baik untuk mengonstruksi model penyelesaian masalah yang tepat. Kemampuan bernalar akan mendukung kinerja mahasiswa dalam menyelesaikan sebuah permasalahan. Kemampuan representasi juga memegang peran yang sangat penting dalam penyerapan informasi terhadap masalah yang dihadapi sebelum menemukan solusi yang sesuai untuk menyelesaikannya.

Maulyda (2018) menyatakan bahwa kemampuan representasi sangat diperlukan untuk memahami sebuah masalah. Representasi akan menentukan pemahaman yang dimiliki mahasiswa ketika diberikan informasi dan masalah. Jika mahasiswa salah dalam menginterpretasikan sebuah permasalahan maka penyelesaian yang didapat juga akan salah. Hal ini sejalan dengan penelitian yang dilakukan Ruliani \& Murtianto (2018) menyatakan bahwa kemampuan representasi yang baik akan membantu seseorang dalam memahami sebuah permasalahan. Salah satu materi dasar matematika yang membutuhkan kemampuan representasi yang baik adalah materi yang berkaitan dengan grafik (Yang, Kabir, \& Hoque, 2016) 
Berdasarkan hasil Kuliah Praktik Lapangan yang dilakukan peneliti pada mahasiswa jurusan Pendidikan Matematika angkatan 2017 menunjukkan bahwa mahasiswa masih mengalami kesulitan dalam memahami grafik fungsi trigonometri. Dalam grafik fungsi trigonometri terdapat tiga jenis grafik fungsi yang dipelajari yakni, grafik fungsi cosus, grafik fungsi kocosus, dan grafik fungsi tangen (Pourdavood, Mccarthy, \& Mccafferty, 2015). Ketiga jenis grafik fungsi tersebut memiliki bentuk umum persamaan yang sama, yakni $A$ Trig $(B x+C)+D$. Mahasiswa harus dapat mengubah fungsi trigonometri ke dalam bentuk grafik, sehingga dibutuhkan kemampuan representasi untuk memahami fungsi trigonometri yang diberikan.

Salah satu media yang dapat digunakan untuk mengubah fungsi ke dalam grafik fungsi adalah menggunakan software GeoGebra. Menurut Bozza (2015), GeoGebra adalah program komputer (software) yang berguna untuk pembelajaran matematika, khususnya geometri dan aljabar. Materi grafik fungsi adalah pokok bahasan matematika yang membutuhkan kecakapan dalam bidang aljabar dan geometri. Penggunaan software GeoGebra diharapkan dapat memberikan pengaruh positif terhadap kemampuan representasi matematis mahasiswa. Hal ini dikarenakan didalam GeoGebra terdapat tampilan aljabar, geometris dan numerik (Oktaria \& Alam, 2016). Selain itu Seloraji \& Eu (2017) juga memaparkan bahwa lewat media GeoGebra pembelajaran matematika akan dapat berjalan dengan baik karena mengandung beragam aktivitas sebagai media demonstrasi dan visualisasi dan sebagai alat bantu konstruksi.

Dalam penelitian-penelitian sebelumnya, software GeoGebra digunakan untuk meningkatkan prestasi belajar siswa pada tingkat sekolah menengah pada materi-materi yang berkaitan dengan grafik fungsi. Seperti pada penelitian yang dilakukan oleh Antohe (2009) yang menggunakan media GeoGebra untuk meningkatkan prestasi belajar matematika siswa SMA. Sementara itu, Stahl, Ou, Weusijana, Ç, \& Weimar (2019) menggunakan media GeoGebra untuk meningkatkan minat dan hasil belajar siswa SMP di Surakarta. Namun, belum ada penelitian yang melihat bagaimana proses representasi seseorang ketika menggunakan media belajar GeoGebra. Berdasarkan paparan diatas, maka penting untuk melihat bagaimana representasi mahasiswa ketika menggunakan media belajar GeoGebra dalam memahami sebuah grafik fungsi trigonometri.

\section{METODE}

Penelitian ini merupakan penelitian kualitatif-deskripif. Pendekatan ini dipilih karena tujuan penelitian ini adalah untuk menggambarkan proses representasi mahasiswa ketika menggunakan media belajar GeoGebra pada materi grafik fungsi trigonometri. Menurut Creswell (2012) penelitian kualitatif adalah prosedur penelitian yang menghasilkan data deskriptif berupa kata-kata tertulis atau lisan dari perilaku yang diamati.

Lokasi penelitian adalah di Universitas Negeri Malang yang terletak di Jalan Semarang 5, Sumbersari, Kec. Lowokwaru, Kota Malang. Subjek penelitian terdiri dari 30 mahasiswa jurusan Pendidikan Matematika angkatan 2017. Dari 30 hasil pekerjaan mahasiswa, terpilih tiga hasil pekerjaan mahasiswa yang dapat mewakili hasil seluruh subjek penelitian. Dua subjek yang terpilih akan diberi kode S1 dan S2 untuk mempermudah proses analisis. Dua hasil pekerjaan siswa ini akan ditelusuri proses representasi yang dilakukannya dalam menyelesaikan soal dan diperkuat dengan wawancara yang dilakukan setelah mahasiswa mengerjakan Lembar Kerja Mahasiswa (LKM) yang diberikan. Indikator representasi yang digunakan sebagaimana ditunjukkan pada tabel 1.

Tabel 1. Indikator Representasi

\begin{tabular}{cl}
\hline \multicolumn{1}{c}{ Aspek Representasi } & \multicolumn{1}{c}{ Indikator } \\
\hline Memahami Grafik Fungsi Trigonometri & Mahasiswa menggunakan representasi verbal (tulisan) dalam memahami \\
& grafik fungsi trigonometri(Y1) \\
& Mahasiswa menggunakan representasi ekspresi matematis untuk memahami \\
& grafik fungsi trigonometri (Y2) \\
& Mahasiswa menggunakan representasi visual untuk memahami grafik fungsi \\
& trigonometri (Y3)
\end{tabular}

Instrumen yang digunakan dalam penelitian ini adalah Lembar Kerja Mahasiswa (LKM) dan wawancara singkat secara tidak terstruktur. Sumber datanya adalah hasil pekerjaan mahasiswa dalam mengerjakan LKM dan hasil wawancara yang dilakukan untuk memperkuat hasil penelitian. Berikut adalah soal yang terdapat dalam LKM yang diberikan kepada mahasiswa. Menggunakan software Geogebra, gambarkan grafik fungsi berikut:

$$
\begin{aligned}
& y=\cos x, \\
& y=(\cos x)+4, \text { dan } \\
& y=(\cos x)-4
\end{aligned}
$$

Bagaimana posisi grafik fungsi poin a terhadap poin $\mathrm{b}$, dan poin a terhadap point $\mathrm{c}$ ? jelaskan!.

Berdasarkan grafik fungsi yang ditampilkan didalam Geogebra, bagaimana pengaruh konstanta D terhadap fungsi $\mathrm{y}=\mathrm{A}$ $\cos (\mathrm{Bx}+\mathrm{C})+\mathrm{D}$ ? 


\section{HASIL}

Hasil pekerjaan dari 30 mahasiswa yang diberikan Lembar Kerja Mahasiswa menunjukkan bahwa semua mahasiswa telah memahami pengaruh perubahan koefisien terhadap grafik fungsi. Hasil ini sejalan dengan hasil penelitian Nurfadilah \& Suhendar (2018) yang menyatakan bahwa GeoGebra akan mempermudah proses pemahaman siswa terhadap grafik geometri. Namun, dalam merepresentasikan hasil pekerjaannya, mahasiswa menggunakan representasi yang berbeda-beda untuk menunjukkan hasil pekerjaannya. Berdasarkan analisis yang dilakukan peneliti, hasil pekerjaan siswa terbagi dalam tiga bentuk yang disajikan pada gambar 7.

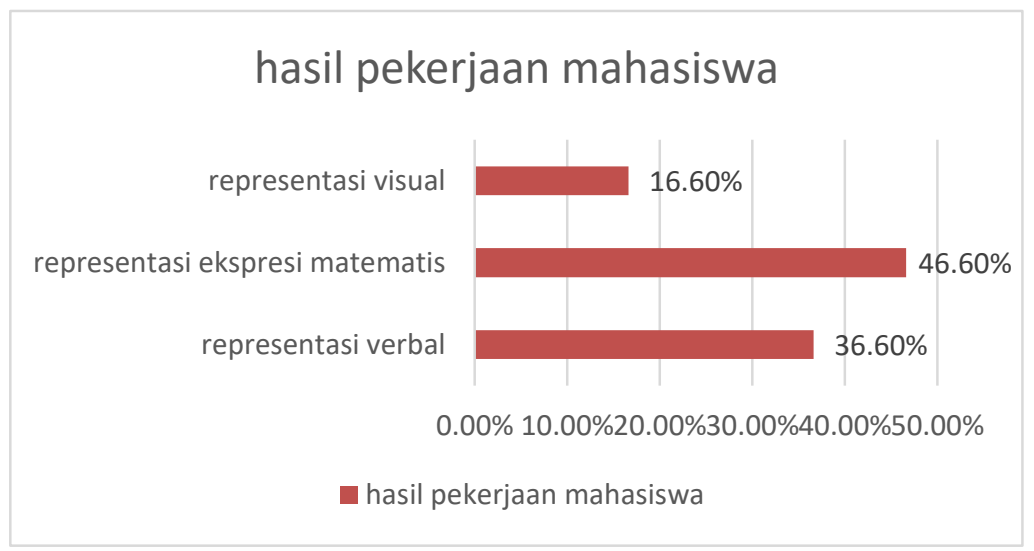

Gambar 7. Diagram Hasil Pekerjaan Siswa

Diagram diatas menunjukkan bahwa 11 mahasiswa menggunakan representasi verbal tulisan, 14 mahasiswa menggunakan ekspresi matematis dan hanya lima mahasiswa yang menggunakan representasi visual. Dari ketiga kecenderungan ini, peneliti memilih satu dari setiap kecenderungan untuk dibahas secara random. Hal ini dilakukan karena peneliti menilai bahwa hasil pekerjaan mahasiswa dapat mewakili hasil pekerjaan mahasiswa yang lain pada tiap-tiap kecenderungan. Sehingga peneliti membuat kode subjek yang akan dibahas, yakni S1untuk subjek yang menggunakan representasi verbal; S2 untuk subjek yang menggunakan representasi ekspresi matematis; S3 untuk subjek menggunakan representasi visual.

\section{PEMBAHASAN}

Sebelum membahas hasil pekerjaan mahasiswa, akan diberikan Gambar 1, 2, dan 3 sebagai hasil untuk perintah Lembar Kerja Mahasiswa pada masing-masing poin (a), (b), dan (c). Gambar tersebut merupakan hasil screenshot tampilan aplikasi geogebra yang muncul ketika persamaan fungsi trigonometri diketik pada aplikasi. Gambar 1, 2, dan 3 digunakan sebagai acuan untuk dibandingkan dengan hasil pekerjaan mahasiswa pada lembar jawaban. Berikut hasil display pada software GeoGebra.

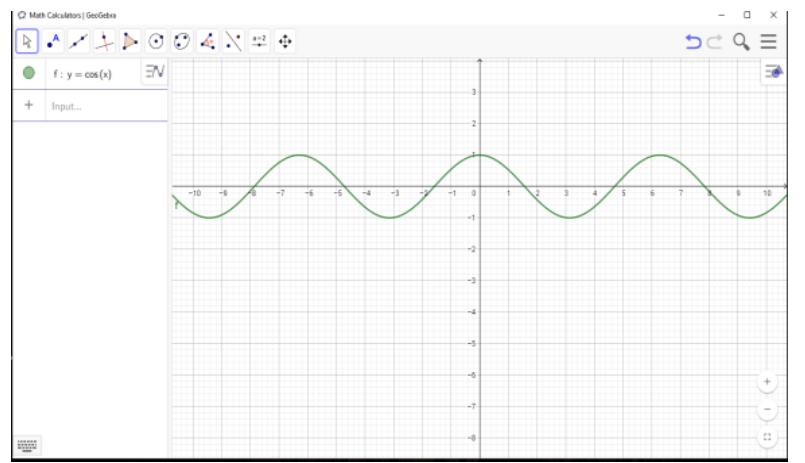

Gambar 1. Tampilan Geogebra Soal Poin a

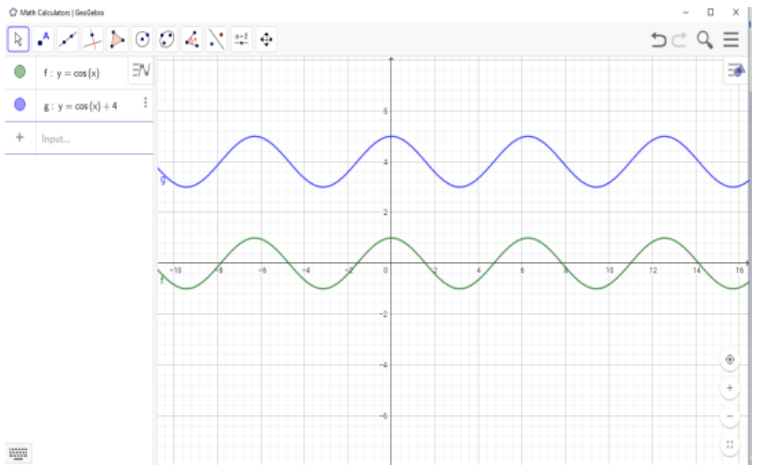

Gambar 2. Tampilan Geogebra Soal Poin b 


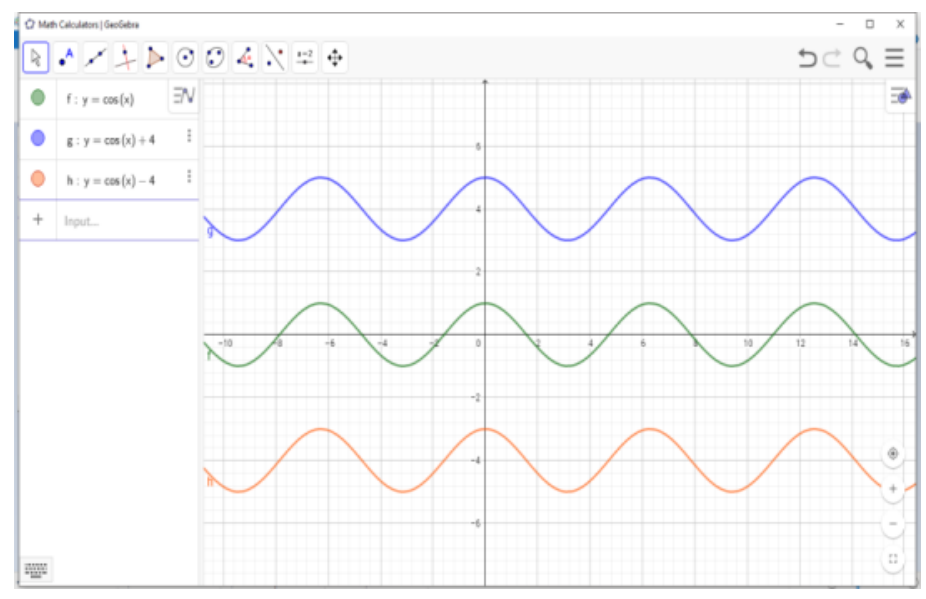

Gambar 3. Tampilan Geogebra Soal Poin C

Subjek S1 merupakan perwakilan dari 11 subjek lain yang menggunakan representasi verbal tulisan untuk merepresentasikan pemahamannya terhadap perubahan konstanta $D$ pada grafik fungsi yang terdisplay pada software GeoGebra. Data ini bertolak belakang dengan hasil penelitian Oktaria \& Alam (2016) yang menyatakan bahwa kebanyakan mahasiswa akan menggunakan gambar atau ekspresi matematis untuk menyelesaikan masalah yang berkaitan dengan grafik, namun subjek S1 menggunakan deskripsi kalimat untuk menyampaikan hasil representasinya. Hal ini terlihat pada gambar 4.

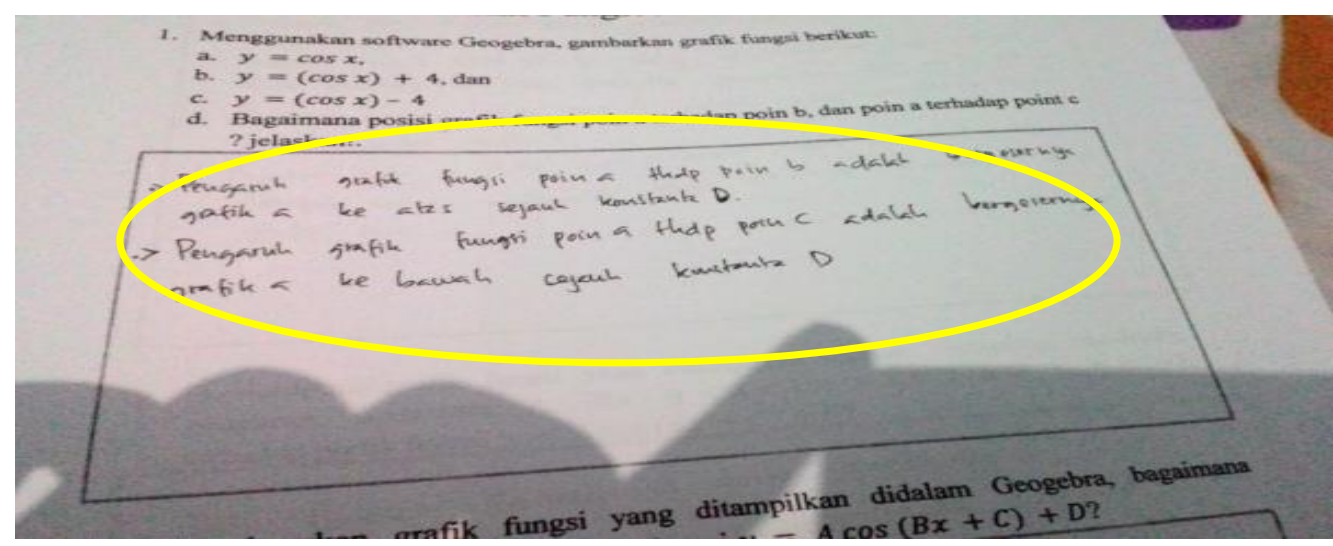

\section{Gambar 4. Hasil Pekerjaan S1}

Pada gambar 4 terlihat bahwa subjek S1 mendeskripsikan secara verbal bahwa perubahan yang terjadi pada grafik fungsi trigonometri adalah pada pergeseran grafik ke atas atau ke bawah sejauh konstanta $D$. Hal ini menunjukan bahwa subjek $\mathrm{S} 1$ telah memahami akibat dari perubahan konstanta $D$ terhadap grafik fungsinya. Selain itu dengan menjawab poin (d), subjek S1 juga telah menunjukkan pemahamannya terhadap perubahan grafik dari fungsi $\cos x$ menuju fungsi $\cos x+4$ dan $\cos x-4$. Pada poin (e) subjek S1 juga berhasil membuat kesimpulan bahwa jika konstanta $D$ bernilai positf (+) maka grafik akan bergeser ke atas, sebaliknya jika konstanta $D$ bernilai negatif(-) maka grafik akan bergeser ke bawah.

\section{Hasil Pekerjaan S2}

Subjek S2 merupakan perwakilan dari 14 subjek lain yang menggunakan representasi ekspresi matematis untuk merepresentasikan pemahamannya terhadap perubahan konstanta $D$ pada grafik fungsi yang terdisplay pada software GeoGebra. Data ini sejalan dengan hasil penelitian Nur, Harahap, Badruzzaman, \& Darmawan (2017) yang menyatakan bahwa banyak siswa menggunakan gambar atau ekspresi matematis untuk menyelesaikan masalah yang berkaitan dengan grafik. Hal ini terlihat pada gambar 5 . 


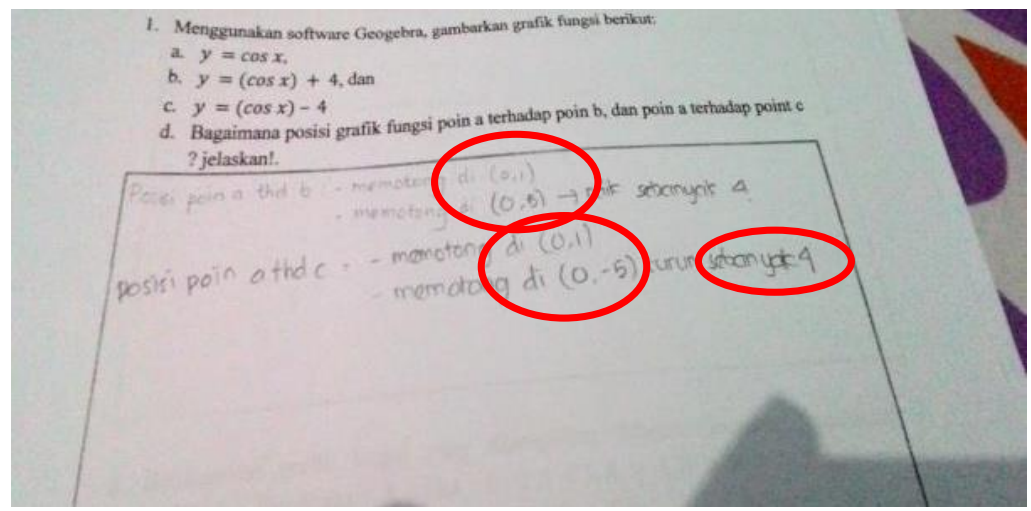

Gambar 5. Hasil Pekerjaan S2

Pada gambar 5 terlihat bahwa subjek S2 mengekspresikan hasil pekerjaannya menggunakan simbol-simbol matematis untuk menunjukkan bahwa perubahan yang terjadi pada grafik fungsi trigonometri adalah pada pergeseran grafik ke atas atau ke bawah sejauh konstanta $D$. Menurut penelitian yang dilakukan Purwanti, Pratiwi, \& Rinaldi (2016) ekspresi matematis ini akan membantu subjek dalam mengekspresikan kalimat-kalimat matematika yang dibaca dari software GeoGebra karena subjek tidak perlu menstranslasi kalimat matematika secara verbal untuk mengekspresikan hasil pekerjaannya. Hal ini menunjukkan bahwa subjek S1 telah memahami akibat dari perubahan konstanta $D$ terhadap grafik fungsinya. Selain itu dengan menjawab poin (d), subjek S1 juga telah menunjukkan pemahamannya terhadap perubahan grafik dari fungsi $\cos x$ menuju fungsi $\cos x+4$ dan $\cos x-4$. Pada poin (e) subjek S1 juga berhasil membuat kesimpulan bahwa jika konstanta $D$ bernilai positf (+) maka grafik akan bergeser ke atas, sebaliknya jika konstanta $D$ bernilai negatif(-) maka grafik akan bergeser ke bawah.

\section{Hasil Pekerjaan S3}

Subjek S3 merupakan perwakilan dari lima subjek lain yang menggunakan representasi verbal tulisan untuk merepresentasikan pemahamannya terhadap perubahan konstanta $D$ pada grafik fungsi yang terdisplay pada software GeoGebra. Data ini sejalan dengan hasil penelitian Kurhan \& Kurhan (2017) yang menyatakan bahwa kebanyakan siswa akan menggunakan gambar atau ekspresi matematis untuk menyelesaikan masalah yang berkaitan dengan grafik. Dilihat dari hasil keseluruhan sangat sedikit anak yang menggunakan representasi visual untuk mengekspresikan hasil pekerjaannya. Namun, lewat bentuk representasi visual, perubahan grafik akan lebih mudah untuk dilihat. Maulyda (2018) sebuah representasi visual akan dapat mewakili berbagai macam bentuk representasi. Hasil tersebut terlihat pada gambar 6.

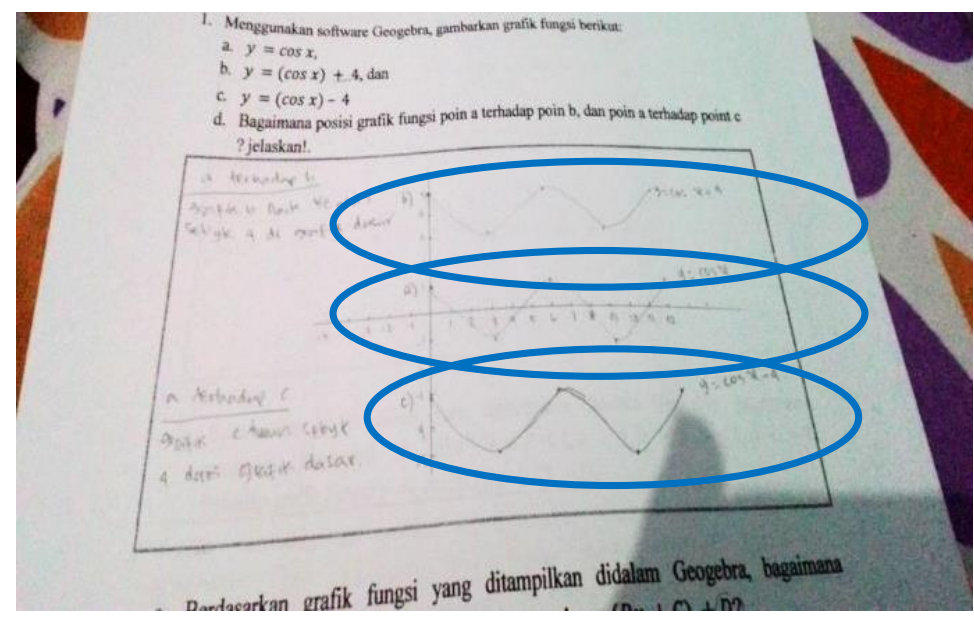

Gambar 6. Hasil Pekerjaan S3

Gambar 6 menunjukkan bahwa mahasiswa menggunakan bentuk representasi gambar untuk menyelesaikan soal. Gambar tersebut merupakan hasil representasi dari display GegoGebra yang merupakan grafik fungsi $y=\cos x, y=\cos x+4$ dan $y=$ $\cos x-4$. Bedasarkan deskripsi yang diberikan untuk mendukung gambar yang dibuat, S3 menuliskan "grafik poin (b) naik 
sebanyak 4" dan "grafik point (c) turun sebanyak 4". Meskipun S3 tidak membuat generalisasi seperti S1 dan S2, S3 sudah dikatakan paham dengan perubahan yang terjadi apabila koefisien $D$ berubah. Hal ini sesuai dengan penelitian Antohe (2009) yang menyatakan bahwa representasi gambar akan diikuti dengan representasi verbal atau ekspresi matematis untuk mendukung gambar yang dibuat.

\section{SIMPULAN}

Berdasarkan hasil penelitian dan pembahasan, dapat disimpulkan bahwa (1) dalam merepresentasikan hasil pekerjaannya mahasiswa cenderung menggunakan tiga bentuk representasi, yakni (a) representasi verbal yang terlihat dari representasi yang berupa kalimat-kalimat, (b) representasi ekspresi matematis yang terlihat dari penggunaan simbol-simbol matematis dalam merepresentasikan tampilan Geogebra, dan (c) representasi visual yang terlihat dari bentuk gambar grafik yang dibuat; (2) ekspresi matematis adalah bentuk representasi yang paling banyak digunakan oleh mahasiswa, sedangkan representasi visual adalah bentuk representasi yang paling sedikit digunakan mahasiswa.

Saran untuk pendidik, meliputi (1) saat pembelajaran matematika pada pokok bahasan geometri, dosen dapat menggunakan GeoGebra sebagai alternatif media pembelajaran agar mahasiswa lebih memahami grafik fungsi; (2) melihat hasil pekerjaan yang menunjukkan bahwa sangat sedikit mahasiswa yang menggunakan representasi visual dalam menyelesaikan pekerjaannya, dosen dapat mengembangkan kemampuan representasi visual ini lewat perkuliahan yang dilakukan.

\section{DAFTAR RUJUKAN}

Antohe, V. (2009). Limits of Educational Soft "GeoGebra" in a Critical Constructive Review. Journal Computer Science Series, 7(2), 47-54.

Bozza, M. (2015). Thinking About the Teaching of Spatial Geometry: Didactic Strategies Using GeoGebra Software and Concrete Materials. Scientia Cum Industria, 3(3), 134-138.

Kurhan, M., \& Kurhan, D. (2017). Railway Track Representation in Mathematical Model of Vehicles Movement. Mathematics Education Research Journal, 3489(72), 40-48. https://doi.org/10.15802/stp2017/118380

Maulyda, A. M. (2018). Representasi Matematis Anak yang Berbakat di Bidang Musik Dalam Menyelesaikan Masalah Matematis. Universitas Negeri Malang.

Nur, I. L., Harahap, E., Badruzzaman, F. H., \& Darmawan, D. (2017). Pembelajaran Matematika Geometri secara Realistis dengan GeoGebra. Jurnal Matematika, 16(2), 1-6.

Nurfadilah, U., \& Suhendar, U. (2018). Pengaruh Penggunaan GeoGebra Terhadap Kemampuan Pemecahan Masalah Siswa pada Topik Garis dan Sudut. Jurnal Matematika dan Pendidikan Matematika, 3(2), 99-107.

Oktaria, M., \& Alam, A. K. (2016). Penggunaan Media Software GeoGebra untuk Meningkatkan Kemampuan Representasi Matematis Siswa SMP Kelas VIII. Kreano: Jurnal Matematika Kreatif-Inovatif, 7(1), 108-116.

Pourdavood, B. R., Mccarthy, K., \& Mccafferty, T. (2015). The Impact of Mental Computation on Children’ s Mathematical Communication, Problem Solving, Reasoning, and Algebraic Thinking. Journal of Mathematical Analysis and Applications, 34(2), 1-13.

Purwanti, R. D., Pratiwi, D. D., \& Rinaldi, A. (2016). Pengaruh Pembelajaran Berbantuan GeoGebra terhadap Pemahaman Konsep Matematis Ditinjau dari Gaya Kognitif. AL-Jabar: Jurnal Pendidikan Matematika, 7(1), 115-122.

Ruliani, I. D., \& Murtianto, Y. H. (2018). Profile Analysis of Mathematical Problem Solving Abilities with Krulik \& Rudnick Stages Judging from Medium Visual Representation. Jurnal Ilmiah Pendidikan Matematika, 7(1), 22-29.

Rusmini, \& Surya, E. (2017). The Effect of Contextual Learning Approach to Mathematical Connection Ability and Student SelfConfidence Grade VIII SMP Negeri 8 Medan. International Journal of Sciences: Basic and Applied Research (IJSBAR), 35(2), 249-262.

Seloraji, P., \& Eu, L. K. (2017). Students' Performance in Geometrical Reflection Using GeoGebra. Malaysian Online Journal of Educational Technology, 5(1), 65-77.

Stahl, G., Ou, J. X., Weusijana, B. K., Ç, M. P., \& Weimar, S. (2019). Multi-User GeoGebra for Virtual Math Teams. Mathematics Education Trends and Research, 3(4), 117-126.

The National Council of Teachers of Mathematics. (2000). Principles and Standards for School Mathematics. Reston, VA: The National Council of Teachers of Mathematics, Inc.

Yang, S., Kabir, M. H., \& Hoque, M. R. (2016). Mathematical Modeling of Smart Space for Context-Aware System : Linear Algebraic Representation of State-Space Method Based Approach. Hindawi Publishing Corporation Mathematical Problems in Engineering, 8(1), 1-8. 